\title{
Vapor Permeation of Aqueous Ethanol through Agarose-Sericin Membrane
}

\author{
Kazunari Okada and Masakazu Yoshikawa*
}

\author{
Department of Biomolecular Engineering, Kyoto Institute of Technology, Matsugasaki, Kyoto 606-8585, \\ Japan
}

\begin{abstract}
A self-standing membrane was obtained from renewable polymers, such as agarose and sericin. Differential scanning calorimetric study revealed that there were two states of water in the membrane, such as bound water and free water. The membrane preferentially transported water from aqueous ethanol mixture by vapor permeation. Preliminary study revealed that the present membrane was applicable to forward osmosis.
\end{abstract}

Keywords: Agarose, Melting Point Depression, Membranes, Vapor Permeation, Sericin.

\section{INTRODUCTION}

Membrane separation is regarded and expected to solve the critical global issues we have faced. As for the critical global issues, the following three types of problem are enumerated; (1) environmental problems, including water pollution, air pollution, etc., (2) energy/resource problems, such as water resources, biomass production, fuel cell, concentration difference power generation and so forth, and (3) health problems, such as artificial organs, hemofiltration, etc. From above, membranes are expected to contribute to support safe, secure and sustainable society.

Among three of critical globe issues, possibility of application of agarose membrane to pervaporation of methanol/methyl tert-butyl ether (MTBE) [1-3], that of aqueous organic mixtures [4,5] and vapor permeation of aqueous ethanol solution [6] was investigated in a link of energy/resource problems. Considering the application of agarose membrane to dehydration of fermentation broth, vapor permeation is thought to be more suitable than pervaporation. In pervaporation, a given membrane is in contact with fermentation broth and this leads to fouling, which causes a reduction of flux. Contrary to this, in vapor permeation, vapor of the permeant is in contact with the membrane, which eliminates the effect of fouling and concentration polarization, which is often observed in liquid phase separation. In the previous study [6], it was revealed that agarose was a promising membrane material for vapor permeation of aqueous ethanol mixture.

Sericin is the second main component in silk cocoons. Sericin is removed in the silk reeling

*Address correspondence to this author at the Department of Biomolecular Engineering, Kyoto Institute of Technology, Matsugasaki, Kyoto 606-8585, Japan; Tel: +81-75-724-7816; Fax: +81-75-724-7800;

E-mail: masahiro@kit.ac.jp processes of the raw silk industry and most of them are abandoned. Sericin is composed of $65 \%$ amino acids that contain hydrophilic amino acid residues, such as serine and aspartic acid, and glycine [7-9]. From this, sericin shows a hydrophilic property. Therefore sericin is used in skin and hair products in cosmetics. The authors' research group also studied the possibility of sericin as a membrane material for ultrafiltration and chiral separation performances [10]. It is an indispensable subject to develop potential utilization of sericin as a raw material in connection with preservation and efficient utilization of natural resources. As one of promising utilization of sericin, a blended membrane was prepared from agarose and sericin and its vapor permeation of aqueous ethanol and forward osmosis ability were studied.

\section{EXPERIMENTAL}

\subsection{Materials}

Agarose (Standard Low- $\mathrm{M}_{\mathrm{r}}$ ) was purchased from Bio-Rad Laboratories and used without further purification. Sericin was kindly provided by SEIREN Co., Ltd. (Tokyo, Japan). Sodium azide and ethanol were used without further purification. Deionized water was employed throughout the experiments.

\subsection{Membrane Preparation}

The membrane was prepared following the procedure previously reported [1]. A $0.40 \mathrm{~g}$ of agarose was dissolved in a $39.60 \mathrm{~g}$ of deionized water. After a $8.0 \mathrm{mg}(0.02 \mathrm{wt} . \%)$ of sodium azide was added as a fungicide, $0.40 \mathrm{~g}$ of sericin was added to the solution and dissolved at $70{ }^{\circ} \mathrm{C}$. The aqueous solution thus prepared was poured onto a tray $(14 \mathrm{~cm}$ long $\times 15 \mathrm{~cm}$ wide), and was allowed to stand at ambient 
temperature. The obtained agarose-sericin gel was sandwiched between two porous Teflon sheets and both outsides were covered with a few sheets of filter papers. The agarose-sericin gel thus covered was allowed to evaporate water at ambient temperature under compression of the constant pressure of $104 \mathrm{~g}$ $\mathrm{cm}^{-2}$. The thickness of the membrane thus obtained was ca. $35 \mu \mathrm{m}$.

\subsection{Differential Scanning Calorimetry (DSC)}

The differential scanning calorimeter used was a Shimadzu DSC-60. A membrane sample was hermetically sealed to prevent evaporation. The sample was cooled down to $-120{ }^{\circ} \mathrm{C}$ at a cooling rate of $5{ }^{\circ} \mathrm{C}$ $\mathrm{min}^{-1}$ by using liquid nitrogen and then heated at a scanning rate of $10{ }^{\circ} \mathrm{C} \mathrm{min}{ }^{-1}$ up to $60{ }^{\circ} \mathrm{C}$. Nitrogen at the flow rate of $300 \mathrm{~cm}^{3} \mathrm{~min}^{-1}$ was used throughout all DSC measurements.

\subsection{Vapor Permeation}

Vapor permeation was carried out at a reflux temperature of each aqueous ethanol mixture, under atmospheric pressure [ca. $0.101 \mathrm{MPa}$ (ca. $1.0 \mathrm{~atm}$ )]. The apparatus was connected to avacuum line and permeate was condensed and trapped by liquid nitrogen in the same manner in the pervaporation experiments [11, 12]. The effective membrane area was $17.3 \mathrm{~cm}^{2}$ and the downstream pressure was maintained at around 66.7 $\mathrm{Pa}$ (ca. $0.5 \mathrm{mmHg}$ ).

Separation analysis was carried out on a Shimadzu GC-7APT gas chromatography instrument with a 3.0$\mathrm{m}$-long column packed with polyethylene glycol 6000 (Shimalite TPA).

The separation factor, $\alpha_{\mathrm{H} 2 \mathrm{O} / \mathrm{EtOH}}$, is defined as

$\alpha_{\mathrm{H} 2 \mathrm{O} / \mathrm{EtOH}}=\left(Y_{\mathrm{H} 2 \mathrm{O}} / Y_{\mathrm{EtOH}}\right) /\left(X_{\mathrm{H} 2 \mathrm{O}} / X_{\mathrm{EtOH}}\right)$

where $Y_{i} \mathrm{~S}$ are the weight fractions in permeate and $X_{i} \mathrm{~S}$ are those in vapor in feed.

\subsection{Estimation of Diffusion Coefficient}

The permeation of $\mathrm{H}_{2} \mathrm{O}$ or ethanol vapor through the membrane in the present study was measured at 78.4 ${ }^{\circ} \mathrm{C}$, which corresponds to the reflux temperature for a weight fraction of $\mathrm{H}_{2} \mathrm{O}$ in liquid feed of ca. 0.10 [13]. From the time-transport curves for each vapor, the apparent diffusion coefficient was determined by applying the time-lag method [14-17].

\section{RESULTS AND DISCUSSION}

\subsection{State of Water in the Agarose-Sericin Membrane}

Before studying vapor permeation performance, the state of water, such as bound (non-freezing) water and bulk (free) water, in the agarose-sericin membrane was investigated. Melting endotherms of water in membrane, of dry membrane and bulk water are shown in Figure 1. The area of endothermic curve at $0{ }^{\circ} \mathrm{C}$ decreased with decrease in water content in the membrane (Figure $\mathbf{3} \mathbf{f}-\mathbf{b}$ ). In Figure $\mathbf{3 c}$ and $\mathbf{b}$, the endotherms of water were hardly observed around its melting point of $0{ }^{\circ} \mathrm{C}$, even though water was still in the membrane. No other new endotherm was observed in the temperature range of $-120^{\circ} \mathrm{C}$ to $60^{\circ} \mathrm{C}$.

(a) $3.00 \times 10^{-4} \mathrm{~g}$-mem.

(b) $0.25 \mathrm{~g}-\mathrm{H}_{2} \mathrm{O} / \mathrm{g}$-mem.

(c) $0.40 \mathrm{~g}-\mathrm{H}^{2} \mathrm{O} / \mathrm{g}$-mem.

(d) $1.50 \mathrm{~g}-\mathrm{H}_{2}^{2} \mathrm{O} / \mathrm{g}-\mathrm{mem}$.

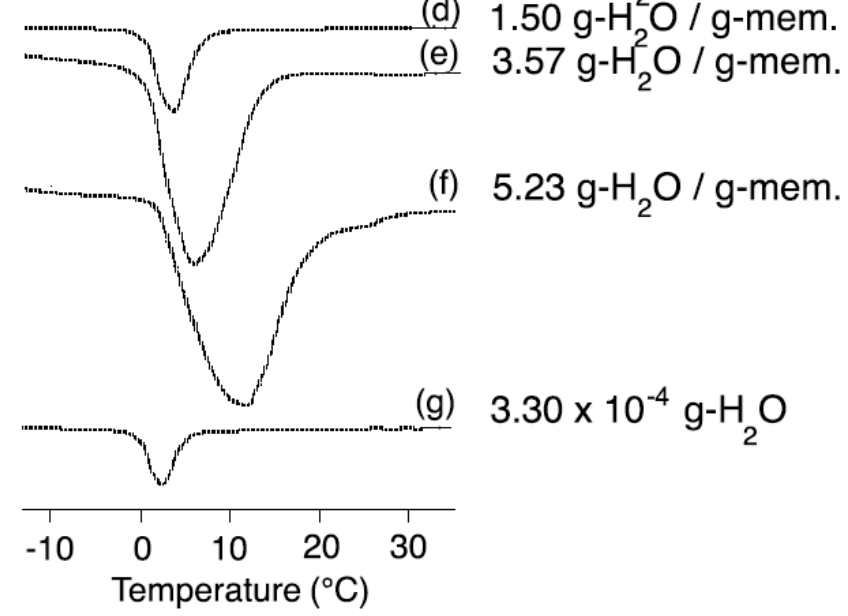

Figure 1: DSC heating curves of agarose-sericin dry membrane (a), membrane water (b-f) and pure water (g).

Figure 2 shows the relationship between enthalpic heat and water content for the membrane. The experimental data showed a straight-line relationship with a slope that was approximately equal to $333.4 \mathrm{~J} \mathrm{~g}^{-1}$ [1820]. Extrapolation to $\Delta H=0$ should intercept at the water content axis at a point that the total bound water in the membrane. The total bound water content was determined to be $0.45 \mathrm{~g}-\mathrm{H}_{2} \mathrm{O} / \mathrm{g}$-membrane. From the fact that bound water was found in the membrane and the results previously reported [6], it is expected that the agarose-sericin membrane showed permselectivity toward water in vapor permeation of aqueous ethanol mixture. To this end, vapor permeation of water-ethanol mixture was investigated, of which results will be given in the next section. 


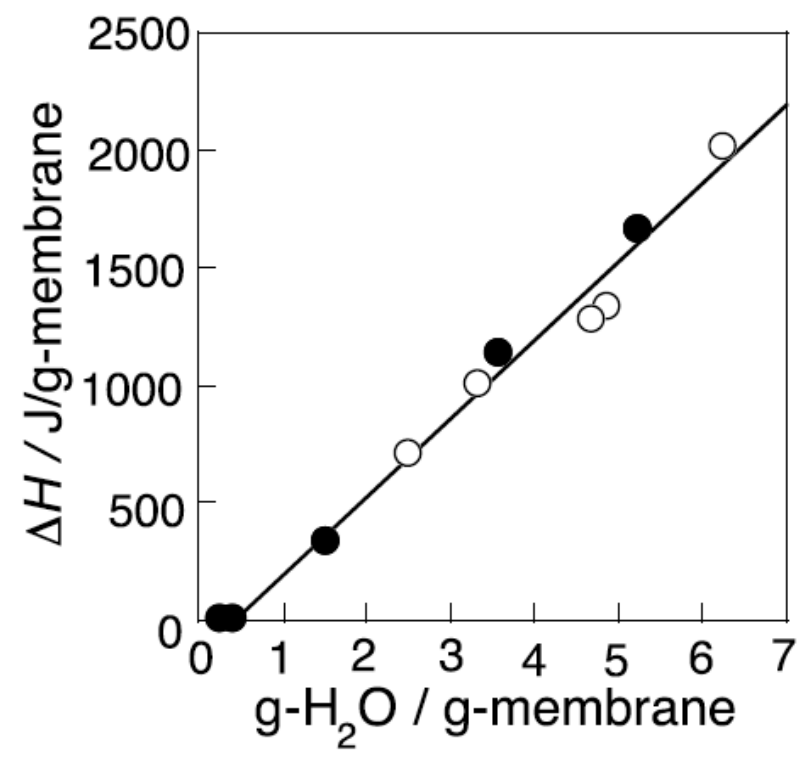

Figure 2: Water content dependence of the heat of melting for freezing water, $\Delta H$, in the agarose-sericin membrane. (The closed circles in the relationship were the data shown in Figure 1).

\subsection{Vapor Permeation of Aqueous Ethanol Mixture}

Vapor permeation results for the present membrane are given in Figure 3 . As expected, the membrane transported water in preference to ethanol. As often observed, permselectivity toward water decreased with the increase in weight fraction of water in feed liquid, while a flux increased with the increase in water content in feed liquid. The vapor permeation performance of the present membrane was inferior to those of the pristine agarose membrane [6]. This might be due to the poor compatibility between agarose and sericin, though, at the moment, authors had no data to support the poor compatibility of those membrane materials. However, the experimental data, supporting the above speculation, will be provided in the next section.

\subsection{Mechanism for the Expression of Permselectivity toward Water Vapor}

It is interesting and indispensable to study the mechanism for the expression of permselecivity for the molecular engineering of vapor permeation membranes. There are two methods to study the factors governing permselectivity. One is that diffusivity selectivity is determined from separation factor and solubility selectivity. The other is a reverse way, solubility selectivity is determined from separation factor and diffusivity selectivity. Though both methods obey solution-diffusion theory [17,21], the governing factors elucidated by the latter method might show a

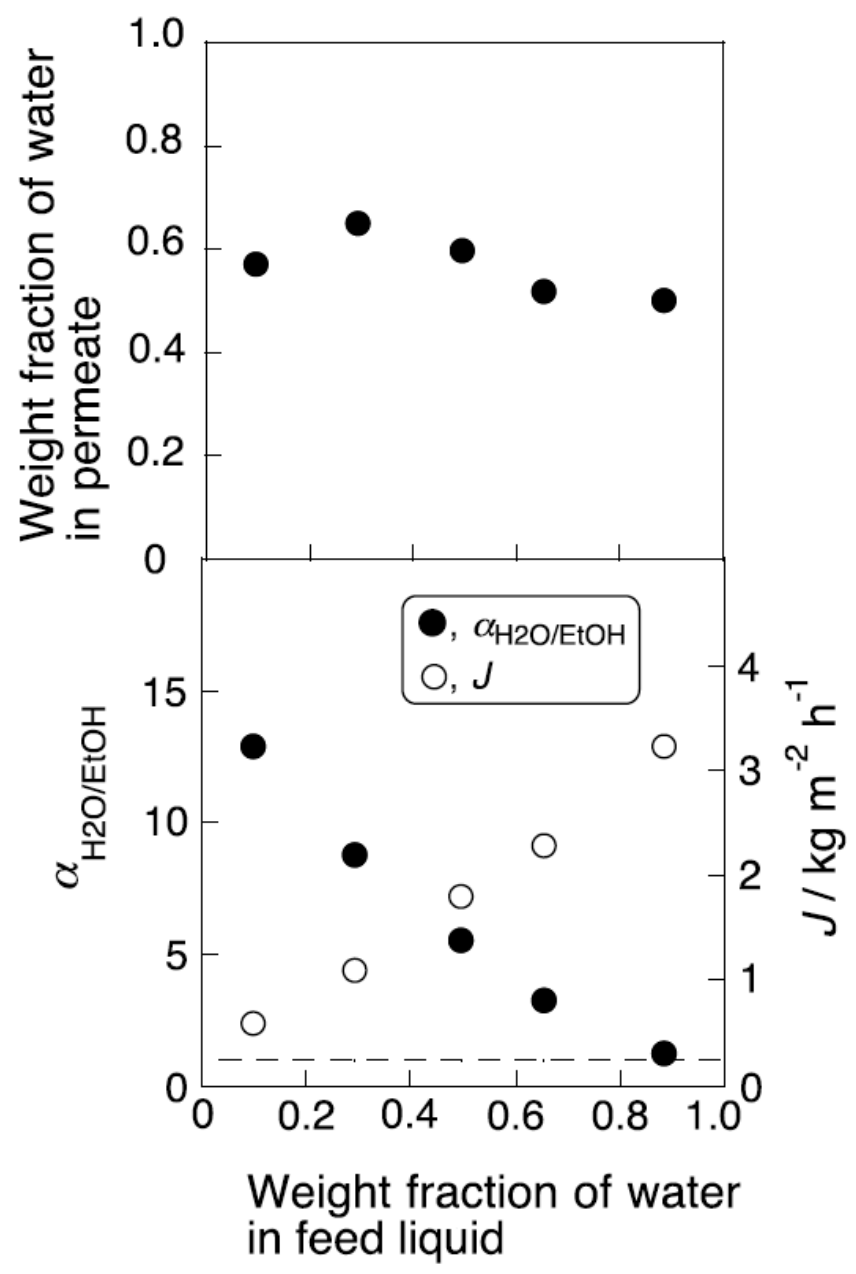

Figure 3: Effect of feed composition on the vapor permeation of $\mathrm{H}_{2} \mathrm{O} / \mathrm{EtOH}$ mixtures through the agarose-sericin membrane. (Downstream pressure, ca. $66.7 \mathrm{~Pa}$ (ca. 0.50 $\mathrm{mmHg}$ ); operating temperature, each reflux temperature).

great accuracy than that by the former method, considering the distribution of permeant in a membrane $[6,22]$. From this, diffusivity selectivity was tried to be determined so that the governing factors for permselectivity could be elucidated.

Time-transport curves of $\mathrm{H}_{2} \mathrm{O}$ vapor at $78.4{ }^{\circ} \mathrm{C}$ are shown in Figure 4 . In the present study, vapor permeation experiments were carried out at each reflux temperature of the aqueous ethanol solution as described in 2.4 , which was not equal to $78.4{ }^{\circ} \mathrm{C}$, which was the reflux temperature of the aqueous ethanol mixture with the weight fraction of water of 0.10 [13]. Diffusion coefficients were determined by the time-lag method [14-17,21] from the permeation data of pure vapor with low activity region. Strictly speaking, the obtained diffusion coefficients determined in the present study are apparent diffusion coefficients since neither sorption isotherm nor state of membrane, such as glassy state or rubbery state, were known [23,24]. 


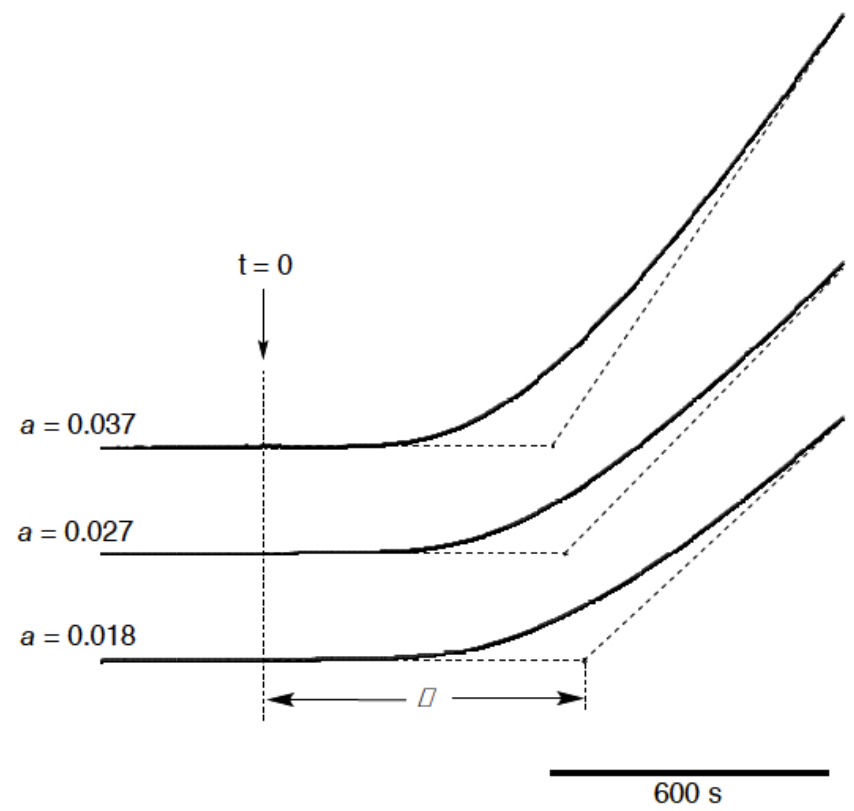

Figure 4: Time-transport curves of $\mathrm{H}_{2} \mathrm{O}$ vapor through the agarose-sericin membrane at $78.4{ }^{\circ} \mathrm{C}$.

The diffusion coefficients of $\mathrm{H}_{2} \mathrm{O}$ are plotted as a function of activity of vapor in Figure 5 . The diffusion coefficient is often dependent on the local concentration of permeant [25-29]. In the present study, the following equation, eq. (2), is used to simulate the concentration dependence of diffusion coefficient for $\mathrm{H}_{2} \mathrm{O}$.

$D=D_{0} \exp (\beta C)$

where $D_{0}$ is the $\mathrm{D}$ value at the permeant concentration approaches $0, \beta$ is the coefficient characteristic of the membrane/permeant interaction and $C$ denotes the permeant concentration in the membrane. From Figure 5, $D_{0}$ was determined to be $2.69 \times 10^{-9} \mathrm{~cm}^{2} \mathrm{~s}^{-1}$ and $\beta$ to be 5.58 .

Contrary to the determination of diffusion coefficient of water, that for ethanol was too high to be determined; at the activity of ethanol vapor of 0.028 , of which vapor pressure of ethanol being $2850 \mathrm{~Pa}(21.4$ $\mathrm{mmHg}$ ) at $78.4{ }^{\circ} \mathrm{C}$, the time lag was less than $1 \mathrm{~s}$. If the time lag was assumed to be $1 \mathrm{~s}$, the diffusion coefficient of ethanol at the activity of 0.028 was elucidated to be $2.04 \times 10^{-6} \mathrm{~cm}^{2} \mathrm{~s}^{-1}$. Comparing the diffusion coefficient of $\mathrm{H}_{2} \mathrm{O}$ for the present membrane, it is unlikely that the diffusion coefficient of ethanol was three orders of magnitude higher than that of $\mathrm{H}_{2} \mathrm{O}$. This might be due to the poor compatibility between agarose and sericin, as suggested in the previous section. The above speculation will be explained by using Figure $\mathbf{6}$. In the diffusion of $\mathrm{H}_{2} \mathrm{O}$ through the agarose-sericin

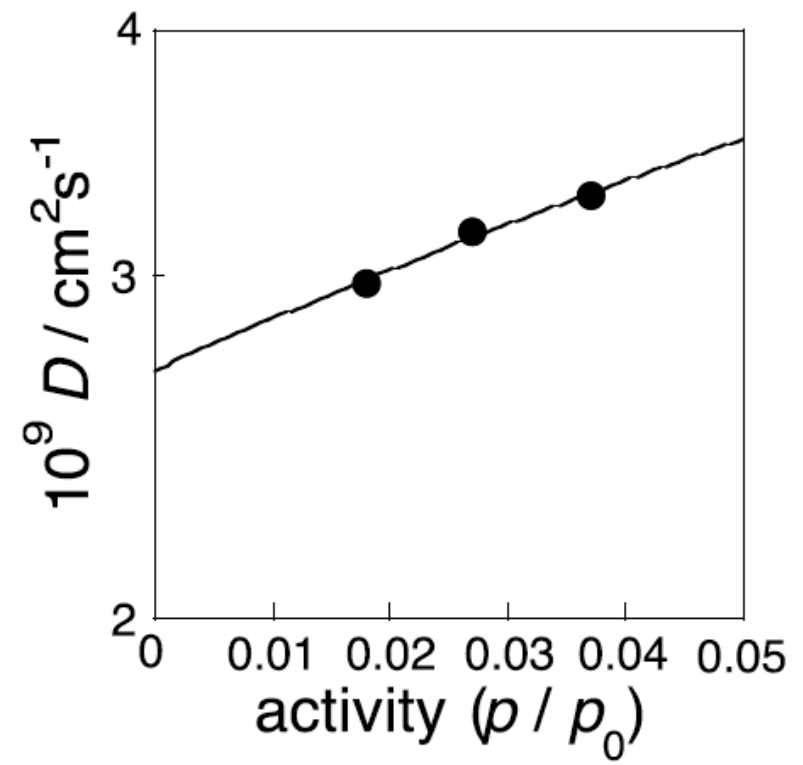

Figure 5: Concentration dependence of diffusion coefficient of water at $78.4{ }^{\circ} \mathrm{C}$. (The saturation vapor pressure $p_{0}$ of water at $78.4^{\circ} \mathrm{C}$ is $44.4 \mathrm{kPa}(333 \mathrm{mmHg})$.

membrane, $\mathrm{H}_{2} \mathrm{O}$ molecule interacted with membrane material, agarose and sericin, by hydrogen bonding and migrated from the upstream side to the downstream side as schematically shown in Figure $\mathbf{6 a}$. In the figure, sericin was depicted as membrane material. Contrary to the diffusion of $\mathrm{H}_{2} \mathrm{O}$, ethanol molecule would not interact firmly with the membrane as shown in Figure $\mathbf{6 b}$ and passed through the defect between agarose and sericin without resistance. If agarose and sericin showed good compatibility, such a fast migration of ethanol could not be occurred. During the vapor permeation of $\mathrm{H}_{2} \mathrm{O}$-ethanol mixtures, even though ethanol would not interact firmly with membrane, the presence of $\mathrm{H}_{2} \mathrm{O}$ prevented a fast migration of ethanol. As a result, as observed in the vapor permeation experiments, water was preferentially transported, though the permselectivity was not so high.

In order to enhance permselectivity toward water, addition of low molecular weight compounds with low vapor pressure to the membrane might be one way so that such compounds lead to good compatibility between agarose and sericin. Introduction of crosslinking might be the other way to narrow gaps between agarose and sericin.

\subsection{Preliminary Study on Forward Osmosis}

The present membrane showed permselectivity toward water by vapor permeation. This stimulated us to study the possibility of forward osmosis [30-32], 
(a) in $\mathrm{H}_{2} \mathrm{O}$

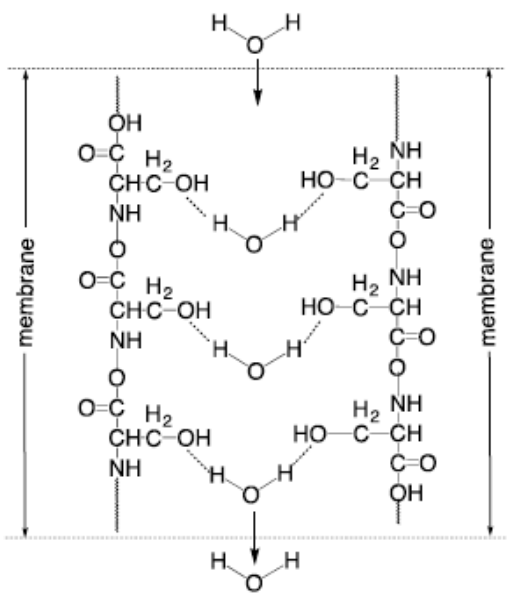

(b) in $\mathrm{EtOH}$

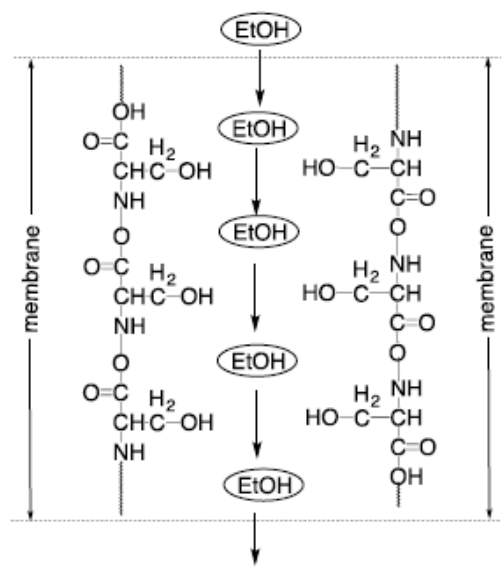

(c) in $\mathrm{H}_{2} \mathrm{O} / \mathrm{EtOH}$

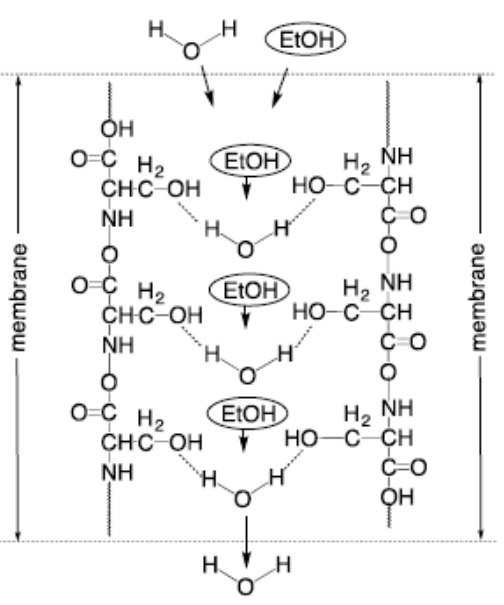

Figure 6: Tentative scheme of diffusion of water (a), ethanol (b) and mixture of water and ethanol (c).

since osmotic converter by mixing fresh water and seawater is expected to be one of renewable and clean energies in the future world [33]. To this end, $25.0 \mathrm{wt} \%$ aqueous $\mathrm{NaCl}$ solution was adopted as draw solution and deionized water as feed, the forward osmosis with the present membrane was preliminarily studied. Water flow of $34.8 \mathrm{~L} \mathrm{~m}^{-2} \mathrm{~h}^{-1}$ was observed.

\section{CONCLUSIONS}

A self-standing membrane was obtained from natural polymers, such as agarose and sericin. Differential scanning calorimetric melting endotherms of the water-swollen membrane were studied to clarify the state of water in the membrane. The results revealed that there were two states of water in the membrane, such as bound water and free water. The membrane transported water in preference to ethanol from aqueous ethanol mixture by vapor permeation. In addition, preliminary study revealed that the present membrane was applicable to forward osmosis.

\section{REFERENCES}

[1] Yoshikawa M, Yoshioka T, Fujime J, Murakami A. Pervaporation separation of $\mathrm{MeOH}-\mathrm{MTBE}$ through agarose membranes. J Membr Sci 2000; 178: 75-78. http://dx.doi.org/10.1016/S0376-7388(00)00478-6

[2] Yoshikawa M, Yoshioka T, Fujime J, Murakami A. Pervaporation separation of $\mathrm{MeOH} / \mathrm{MTBE}$ with hydrophilic polymer/agarose blended membranes. Membrane 2001; 26: 259-264.

http://dx.doi.org/10.5360/membrane.26.259

[3] Yoshikawa M, Yoshioka T, Fujime J, Murakami A. Pervaporation separation of methanol/methyl tert-butyl ether mixtures through agarose/hydroxylethylcellulose blended membranes. J Appl Polym Sci 2002; 86: 3408-3411. http://dx.doi.org/10.1002/app.11347
[4] Masaki K, Yoshikawa M. Pervaporation of aqueous organic mixtures through agarose membranes. Membrane 2001; 26: 155-157.

http://dx.doi.org/10.5360/membrane.26.155

[5] Yoshikawa M, Masaki K, Ishikawa M. Pervaporation separation of aqueous organic mixtures through agarose membrane. J Membr Sci 2002; 205: 293-300. http://dx.doi.org/10.1016/S0376-7388(02)00131-X

[6] Fujita Y, Yoshikawa M. Vapor permeation of aqueous ethanol mixtures through agarose membranes. J Membr Sci 2014; 459: 114-121.

http://dx.doi.org/10.1016/j.memsci.2014.01.052

[7] Takatsu $\mathrm{Y}$, Yamada $\mathrm{H}$, Tsubouchi $\mathrm{K}$. Isolation of three main sericin components from the cocoon of the silkworm, Bombyx mori. Biosci Biotechnol Biochem 2002; 66: 2715-2718. http://dx.doi.org/10.1271/bbb.66.2715

[8] Mondal M, Trivedy K, Kumar SN. The silk proteins, sericin and fibroin in silkworm, Bombyx mori. Caspian J Env Sci 2007; 5: 63-76.

[9] Sothornvit R, Chollakup R, Suwnruji P. Extracted sericin from silk waste fro film formation. Songklanakarin J Sci Technol 2010; 32: 17-22. Rdo.psu.ac.th/sjstweb/journal/32-1/-1253359-32-1-17-22.pdf

[10] Yamada H, Fuwa N, Nomura M, Yoshikawa M, Kunugi S Utilization of sericin as raw materials for specialty polymers. 1 Ultrafiltration performance of sericin membrane. Membrane 1993; 18: 301-303. http://dx.doi.org/10.5360/membrane.18.301

[11] Yoshikawa M, Higuchi A, Ishikawa M, Guiver MD, Robertson GP. Vapor permeation of 2-propanol solutions through gelatin/Torlon poly(amide/imide) blended membranes. J Membr Sci 2004; 243: 89-95. http://dx.doi.org/10.1016/j.memsci.2004.05.033

[12] Yoshikawa M, Kawamura K, Ejima A, Aoki T, Watanabe K, Guiver MD, Robertson GP. Thermostable natural protein polymers from Geobacillus thermodenitrificans DSM465 as membrane materials for vapor permeation. Membrane 2004; 29: 384-387. http://dx.doi.org/10.5360/membrane.29.384

[13] Hughes HE, Maloney JO. The application of radioactive tracers to diffusional operations. Binary and ternary equilibrium data. Chem Eng Prog 1952; 48: 192-200.

[14] Crank J, Park GS. Diffusion in polymers. London: Academic Press 1968. 
[15] Crank J. Mathematics of diffusion. 2nd ed. Oxford: Clarendon Press 1975.

[16] Vieth WR. Diffusion in and through polymers. Principles and applications. München: Hanser 1991.

[17] Mulder M. basic principles of membrane technology. 2nd ed. Dordrecht: Kluwer Academic Publishers 1996.

[18] Riddick JA, Bunger WB, Sakano TK. Organic Solvents. 4th ed. New York: Wiley 1986.

[19] Higuchi A, lijima T. D.s.c. investigation of water in poly(vinyl alcohol) membranes. Polymer 1985; 26: 1207-1211. http://dx.doi.org/10.1016/0032-3861(85)90254-X

[20] Higuchi A, lijima T. D.s.c. investigation of the state of water in poly(vinyl alcohol-co-itaconic acid) membranes. Polymer 1985; 26: 1833-1837.

http://dx.doi.org/10.1016/0032-3861(85)90011-4

[21] Baker RW. Membrane Technology and Applications. 2nd ed. West Sussex: Wiley 2004. http://dx.doi.org/10.1002/0470020393

[22] Yamada S, Hamaya T. Liquid permeation and separation by surface modified polyethylene membranes. J Membr Sci 1984; 17: 125-138. http://dx.doi.org/10.1016/S0376-7388(00)82290-5

[23] Paul DR, Koros WJ. Effect of partially immobilizing sorption on permeability and the diffusion time lag. J Polym Sci Polym Phys Ed 1976; 14: 675-685.

http://dx.doi.org/10.1002/pol.1976.180140409

[24] Koros WJ, Paul DR. Transient and steady-state permeation in poly(ethylene terephthalate) above and below the glass transition. J Polym Sci: Polym Phys 1978; 16: 2171-2187. DOI: $10.1002 /$ pol.1978.180161207

[25] Park GS. The diffusion of some halo-methane in polystyrene. Trans Faraday Soc 1950; 46: 684-697. http://dx.doi.org/10.1039/tf9504600684
[26] Rouse Jr PE. Diffusion of vapors in films. J Am Chem Soc 1947; 69: 1068-1073.

http://dx.doi.org/10.1021/ja01197a029

[27] Rogers CE, Stannet V, Szwarc M. The sorption, diffusion, and permeation of organic vapors in polyethylene. J Polym Sci 1960; 45: 61-82. http://dx.doi.org/10.1002/pol.1960.1204514506

[28] Mares $P$. Transient permeation of organic vapors through polymer membranes. J Appl Polym Sci 1965; 9: 917-932. http://dx.doi.org/10.1002/app.1965.070090310

[29] Cabasso I. Organic liquid mixtures separation by permselective polymer membranes. 1. Selection and characteristics of dense isotropic membranes employed in the pervaporation process. Ind Eng Chem Prod Res Dev 1983; 22: 313-319. http://dx.doi.org/10.1021/i300010a029

[30] Zhao S, Zou L, Tang CY, Mulcathy D. Recent development in forward osmosis opportunities and challenges. J Membr Sci 2012; 396: 1-21.

http://dx.doi.org/10.1016/j.memsci.2011.12.023

[31] Chekll L, Phuntsho S, Shon HK, Vigneswaran S, Kandasamy $\mathrm{J}$, Chanan A. A review of draw solutes in forward osmosis process and their use in modern applications. Desal Water Treat 2012; 43: 167-184. http://dx.doi.org/10.1080/19443994.2012.672168

[32] Chung TS, Li X, Ong TC, Ge Q, Wang H, Han CH. Emerging forward osmosis (FO) technologies and challenges ahead for clean water and energy applications. Curr Opin Chem Eng 2012; 1: 246-257. http://dx.doi.org/10.1016/j.coche.2012.07.004

[33] Norman RS, Water salination: A source of energy. Science 1974; 186: 350-352. http://dx.doi.org/10.1126/science.186.4161.350

\section{DOI: http://dx.doi.org/10.6000/1929-6037.2015.04.03.3}

(C) 2015 Okada and Yoshikawa; Licensee Lifescience Global.

This is an open access article licensed under the terms of the Creative Commons Attribution Non-Commercial License (http://creativecommons.org/licenses/by-nc/3.0/) which permits unrestricted, non-commercial use, distribution and reproduction in any medium, provided the work is properly cited. 